\title{
The effect of financial ratios on systematic risk index
}

\author{
Ali Faez ${ }^{a}$ and Babak Eslam ${ }^{b^{*}}$
}

${ }^{a}$ Department of Accounting, Science and Research Semnan Branch, Islamic Azad University, Semnan, Iran

${ }^{b}$ Department of Management and Accounting, Science and Research Semnan Branch, Islamic Azad University, Semnan, Iran

\section{H R O N I C L E}

\section{Article history:}

Received June 22, 2013

Received in revised format

28 August 2013

Accepted 27 September 2013

Available online

September 302013

Keywords:

Financial Ratios

Systematic Risk

Tehran Stock Exchange

\section{Introduction}

Risk and return are considered as the most important criteria for making appropriate investment strategies. When the future events are not entirely predictable and some events are preferred to others, there are some risk factors. When there are good awareness on risk and rewards of firms, it is getting easier to make appropriate investment strategies. According to the financial literature, risk is normally defined as the probability of actual return and the expected return and it is divided into two categories: The first category includes some risks, which are associated with internal factors of the company, such as management risk, cash risk, and risk of disability in paying debts called unsystematic risk (controllable risk). The second category includes the risks, which are not associated with one or more companies, but it is more related to general market conditions such as economic, political and social conditions etc. known as systematic risk $(\beta)$.

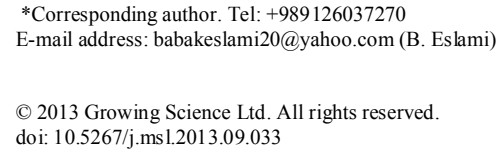

\begin{abstract}
This paper investigates the relationship between financial ratios and indicator of systemic risk in the Tehran Stock Exchange. The study selects 73 manufacturing companies of the Tehran Stock Exchange market over the period 2003-2010. The study first calculates the independent variables in the form of financial ratios and then the ratios affecting the systematic risk index are extracted using entropy method. The output of this stage is the introduction of five influential financial indicators as the independent variables of the study. Using t-test and index is evaluated and finally, using stepwise regression method, the effect of independent variables on the dependent variable is examined. According to results of our survey, the correlation coefficient of such indices as "the ratio of stock price to the profit of each share", "Current ratio", "each share profit ratio" and "the stockholders rights return ratio" have respectively the highest correlation with the systematic risk index.
\end{abstract}

(C) 2013 Growing Science Ltd. All rights reserved. 
Since the systematic risk $(\beta)$ is uncontrollable and cannot be reduced, so it plays an essential role in the decisions of the companies' managers and investors (Bildersee, 2003). In this paper, we try to understand whether or not there is a relationship between the systematic risk $(\beta)$ of the common shares of the companies admitted in Tehran stock exchange and accounting criteria. We also look to find out the level of the systematic risk $(\beta)$ associated with the changes of these criteria.

\section{Literature Review}

\subsection{Risk}

According to Glib (2002) "any phenomenon that can deviate the result from what is expected by investor is called the risk". Markowitz (Markowitz, 1952) is believed to be the first who introduced the idea of risk/reward mode based on some quantitative definitions and introduced the numerical indicator for risk. He defined risk as a multi-period standard deviation of a variable. Others defined risk as the possibility of the reduction in income or losing the capital (Jones, 1991). All individuals and market participants escape from the risk or allow an acceptable level of risk. The risk concept is hugely applied in financial domain because of the fact that participants of the market ask about the risk level when they face with any kind of stock exchange. Most investors are looking for return and the concept of risk is introduced to determine a hedge against any possible losses.

Indeed, the risk/reward is considered as two main bases of the decision making for investors. We always expect the higher risk is associated with higher return and vice versa. The risk concept plays a key role in financial market. So, one has to know it and measures it and takes necessary actions to remove the unnecessary risks. When there is a risk with any opportunity and basically one cannot eradicate all risks, it is getting difficult to make appropriate investment decisions. Overall risk is among the first concerns of investors. However, the successful investors are those who allow an acceptable level of risk. Because they are aware of the fact that one cannot analyze the certain results and higher return, simultaneously. Risk of financial assets, considering the fact that it is kept in the short term, will be different from the state in which one invests for a long period of time. There are differences between the conditions of uncertainty and risk. The lack of accurate information about future events is the same as the lack of detailed information about upcoming events.

\subsection{Financial ratios}

\section{The expected range rates}

The rate where we will have in future considering the anticipation of the profit and stock price (Goudarzi, 2004).

\section{The ratio of each share profit}

Each share profit is a ratio that express the periodical profit of the corporation based on each share of main owners namely ordinary share. This ratio is the only proportion that is necessary to be present in the financial reports (Noravesh, 2006).

\section{Current Ratio}

According to Jahankhani (2005), one of the liquidity ratios for measuring the company's ability to repay short-term commitments and is calculated as follows:

$$
\text { Current Ratio }=\text { current assets/ current debts }
$$

\section{The ratio of stock price to the profit of each share}

According to Jahankhani (2005), to calculate the ratio, the profit after deducting the tax is divided by the number of ordinary shares on the hand of shareholders. 


\section{The ratio of net profit to sale}

By this ratio, the profitability of each Rial of the sale is calculated, in such a way that the amount of profit after deducting the tax is divided by the net sale ratios.

\section{The ratio of the shareholders rights return}

Using this ratio, the companies profit per each Rial of the shareholders rights is calculated. The profit after deducting the tax is divided by the shareholders' rights.

\section{Research methodology}

Considering the objective of this research, it is an applied research. Also according to the type of data, the research is ex post facto since the recent year data are examined. Since in the longitudinal (time series) research, the information of several companies is studied in one or more financial year, therefore, considering the overall design for the required data collection, this study is a crosssectional study.

\subsection{Population, sampling, sample size}

The research population includes the companies listed in Tehran Stock Exchange whose fiscal year has ended in March, and their information is available. In order to determine the desirable samples in this study, given the multiplicity of stock companies, their activity type, their different sizes etc., the conditional sampling method was used. In other words, some conditions are defined for homogenization of the research subject, and companies that have all the mentioned conditions are considered as participants. Among all stock companies, those who have all following conditions are considered as a participant.

- The given companies have been enrolled in the stock from march-April, 2001.

- Trading on their stock is not long interrupted (more than 5 months).

- The company is not among the investment companies and financial intermediation since they lack accruals.

- The end of companies' financial year is leading march 29th.

According to the above conditions, the samples of the present study were extracted using the "Rahavard-e-Novin" software and among the 100 TSE listed firms in 2001, 73 companies were selected, which form 59\%of the whole stock market value in the end of 2001.

\subsection{Research hypotheses:}

- First hypothesis: There is a significant relationship between current ratio and the systematic risk index of companies listed in Tehran stock exchange.

- Second hypothesis: There is a significant relationship between the ratio of each share profit and the systematic risk index of the companies listed in Tehran stock exchange.

- Third hypothesis: There is a significant relationship between the ratio of stocks price to each share profit and the systematic risk index of the companies listed in Tehran stock exchange.

- The fourth hypothesis: There is a significant relationship between the ratio of net profit to sale and the systematic risk index of the companies listed in Tehran stock exchange.

- The fifth hypothesis there is a significant relationship between the shareholders rights return and the systematic risk index of the companies listed in Tehran stock exchange.

\section{Data analysis}

\subsection{Determination of effective indices based on entropy method}

In all of the issues regarding the evaluation and assessment, the presence of indices as the main criterion for evaluation is needed. 
First we must identify the indices and the indices that are most common include:

Leverage ratios include:

$\mathrm{X}_{1}$ : Debt to asset ratio $\mathrm{X}_{2}$ : Debt to the shareholders' rights ratio $\mathrm{X}_{3}$ : Financial expenses coverage

Profitability ratios include:

$\mathrm{X}_{4}$ : net profit to assets (ROA) $\mathrm{X}_{5}$ : net profit to net sales $\mathrm{X}_{6}$ : gross profit to net sales

$\mathrm{X}_{7}$ : Net profit to shareholders' rights (ROE)

The activity ratios include:

$\mathrm{X}_{8}$ : trade receivables accounts to net sales $\quad \mathrm{X}_{9}$ : Sales to assets

Liquidity ratios include:

$\mathrm{X}_{10}$ : current ratio (current assets/current debt) $\mathrm{X}_{11}$ : The immediate ratio (immediate asset/current debt)

$\mathrm{X}_{12}$ : working capital to assets $\mathrm{X}_{13}$ : cash holdings to assets $\mathrm{X}_{14}$ : cash holdings to current debts

Each index is scored by these managers. In the first stage, we convert this qualitative information into quantitative ones. For this, we used hour spectrum and in the second stage we normalized the obtained matrix and there were different methods for normalization of the matrix, including hour norm, linear norm and Euclidean norm, that in the present research we used hour norm which is the most common method. In the third stage we extract the indices' weight. There are different criteria for determining the indices weight. One of the most important mathematical methods for determining the indices security coefficient is entropy method which is employed in this study. The criteria for weighing in these indices is the rate of information produced from each index, so that the index which can establish more distinction between the options, provides more information for decision maker. So, it should have more importance.

With regard to the calculations of our input variables in the system, 5 input variables are as follows:

- The ratio of each share profit

- The ratio of share price to each share profit

- The ratio of shareholders' right return

- Current ratio

- Net profit to sale ratio

\subsection{Evaluation of research hypotheses}

This section investigates and tests research hypotheses. Five hypotheses in this study have been considered to investigate the relationship between the variables. In order to test the research hypotheses, Pearson's correlation have been used to assess the relationship between independent and the dependent variables of the study:

\section{Estimating the Pearson correlation coefficient:}

Correlation coefficient is a statistical tool in which the degree that one variable is linearly related to another variable is measured. Regarding the fact that research hypotheses provide the relationship between two variables, so the correlation coefficient was used to accept or reject the hypotheses: 
Table 3

The correlation coefficient between independent variables and systematic risk

\begin{tabular}{lcc}
\hline Independent variable & Pearson coefficient & Level of significance \\
\hline Current ratio & 0.679 & 0.000 \\
The ratio of each share profit & 0.526 & 0.008 \\
The ratio of share price to each share profit & 0.782 & 0.013 \\
The ratio of net profit to sale & 0.113 & 0.300 \\
The ratio of shareholders' rights return & 0.456 & 0.008 \\
\hline
\end{tabular}

In all cases where the amount of model variables Sig is smaller than the error level, $\mathrm{H}_{0}$ hypothesis is rejected and $\mathrm{H}_{1}$ is the confirmed. In other word, with regard to the Pearson correlation coefficient, there is a significant relationship between all independent variables except the variable of net profit to sales ratio with dependent variable at $95 \%$ confidence level.

In other words, all five research hypotheses (except the relationship between net profit to sales ratio and systematic risk) are confirmed

\subsection{Relationship between study variables using stepwise regression}

Considering that Pearson's correlation estimate the type and size of the relationship between each independent variable separately with systematic risk and equations in which only the systematic risk variable and one of five given independent variables are brought, therefore, to estimate more accurately and determination of the coefficient of the significance of each of the five independent variables on systematic risk, considering and involving other variables, the stepwise regression method should be used. Now, using stepwise regression, the following steps are taken:

\section{Table 4}

The order of inserting the data in the stepwise regression

\begin{tabular}{|c|c|c|c|}
\hline Stage & The order of inserting the variables & Estimating equation & $\begin{array}{l}\text { Explaining } \\
\text { coefficient }\end{array}$ \\
\hline 1 & $\begin{array}{l}\text { ratio of share price to each share } \\
\text { profit }\end{array}$ & $\mathrm{Y}=0.169+0.782 \mathrm{X}_{3}$ & 0.112 \\
\hline 2 & current ratio & $Y=0.123+0.642 X_{3}+0.519 X_{1}$ & 0.271 \\
\hline 3 & ratio of each share profit & $Y=0.143+0.612 X_{3}+0.452 X_{1}+0.346 X_{2}$ & 0.38 \\
\hline 4 & ratio of shareholders' right return & $Y=0.101+0.601 X_{3}+0.439 X_{1}+0.309 X_{2}+0.297 X_{5}$ & 0.509 \\
\hline
\end{tabular}

The amount of the final determination coefficient, namely, $\mathrm{R}_{2}$ is equivalent to 0.509 , indicating that $51 \%$ of the changes in systematic risk variable may be predicted through the ratio of share price to each share profit, current ratio, the ratio of each share profit and the ratio of shareholders' right return.

\section{5. summary and suggestions}

According to Pearson correlation coefficient test, there is a significant correlation between all independent variables except for the variable of net profit to sale ratio with dependent variable at $95 \%$ confidence level. In other words, all five research hypotheses, excluding the relationship of net profit to sales ratio variable with systematic risk, are confirmed.

Correlation coefficients of such indices as "the ratio of share price to each share profit", "Current ratio", "the ratio of each share profit" and "the ratio of shareholders' rights return" have respectively the highest correlation with the systematic risk index. So, it is suggested that for studying and predicating the systematic risk of the stock companies, the indices and above ratios be emphasized. 
In the present study, the single-variable regression was employed for studying the relationship between the financial ratios and systematic risk. Using multi-variable regressions and studying the simultaneous effect of variables on the systematic risk in the studied companies may be the subject of the other study in this field.

\section{References}

Ahmadpour, G. (1998). Systemic risk prediction using accounting information. PhD. Thesis, 1998.

Bildersee, J. S. (1975). The association between a market-determined measure of risk and alternative measures of risk. The Accounting Review, 50(1), 81-98.

Brimble, P., Oldfield, D., \& Monsakul, M. (2002). 8 Policies for SME Recovery in Thailand. The role of SMEs in national economies in East Asia, 2, 202.

Gilb, T. (2002). Risk Management: A practical toolkit for identifying. Analyzing and coping with project risks. $w$ ww. result-planning.com.

Godarzi, M. (2006). The Journal of Tehran Stock Exchange, No 10, [In Persian].

Jahankhani, A., \& Parsaian, A. (1999). Securities, investment management and evaluation. Publication of Management Collage Tehran university [In Persian].

Jalilian, Y., \& Akbari, P. (2011). The role of financial innovation in economic development, Economic Journal, 43.

Jones, C. P. (2007). Investments: analysis and management. Wiley. com.

Khajavi, S. (2005). Empirical models designed to estimate the systematic risk of listed companies on the Stock Exchange by using accounting variables. Master of Science Thesis, Tehran University.

Markowitz, H. (1952). Portfolio Selection. The Journal of Finance, 7(1). 77-91.

Noravesh, I. (2006). Investment policies for Iran stock exchange investment. Auditor (Hesabres) Journal, 40-41 [In Persian].

Noravesh, I. (2008). An accounting system in developing countries, The Journal of Tehran Stock Exchange, 12, 13. 